\title{
Формы реализации судебной власти в уголовном судопроизводстве в контексте процессуального статуса суда как участника уголовного процесса
}

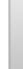
Check for
updates

Луценко П.А., кандидат юридических наук, доцент кафедры уголовного права и уголовного процесса Воронежского ГАУ им. императора Петра I

\begin{abstract}
Аннотация. В статье анализируется процессуальный статус суда как участника уголовного судопроизводства с учетом специфики его правового положения и реализуемых функций. Правовой статус суда в уголовном судопроизводстве детерминируется отсутствием публичного либо личного интереса в исходе уголовного дела, что не только предопределяет состязательную форму судопроизводства, но и является гарантией независимости судебной власти при осуществлении правосудия. Автор приходит к выводу о том, что понятие «суд» является собирательным, поскольку с одной стороны - это государственное учреждение, входящее в судебную систему, с другой стороны - судья является носителем власти, рассматривающим уголовное дело по существу и выносящим решения, предусмотренные законом.

Судебная система обладает признаком инстанционности, обусловленным ее внутренней иерархической структурой. Наличие судебных инстанций предопределяет движение уголовного дела, является структурным механизмом реализации функции внутреннего судебного контроля и надзора, а также обеспечивает защиту прав и законных интересов участников уголовного судопроизводства и иных заинтересованных лиц. Полномочия суда рассматриваются с позиций функционального критерия, а именно: разрешение уголовного дела по существу; контроль за деятельностью органов предварительного расследования; рассмотрение жалоб на действия (бездействие) и решения должностных лиц, ведущих производство по уголовному делу; реагирование на допущенные в ходе производства по уголовному делу нарушения прав и свобод граждан, принципа законности, установленные обстоятельства, способствовавшие совершению преступления путем вынесения частного определения или постановления.
\end{abstract}

Ключевые слова: суд, разрешение уголовного дела по существу, судебный контроль, санкционирование, жалоба, меры принуждения, следственные действия.

$\mathrm{B}$ опрос о формах и способах реализации судебной власти в уголовном судопроизводстве, на наш взгляд, необходимо анализировать с точки зрения правового статуса суда как участника уголовно-процессуальных отношений. Таковые перечислены законодателем в разд. ІІ УПК РФ и классифицированы на следующие группы: суд; участники уголовного процесса со стороны обвинения; участники уголовного процесса со стороны защиты; иные участники уголовного процесса.

Мы полагаем, что приведенный выше легальный подход позволяет говорить об обособленности судебной власти в уголовном судопроизводстве с точки зрения правового статуса (гл. 5 УПК РФ). В состязательном судопроизводстве суд реализует исключительные полномочия, связанные с осуществлением правосудия, что обусловливает специфику его положения, которая, на наш взгляд, заключается в следующем.
1. Понятие «суд» по своему содержанию может быть отнесено к числу комбинированных, поскольку с одной стороны суд относится к числу государственных органов, совокупность которых формирует судебную систему, реализующую самостоятельную ветвь государственной власти (ст. 1 ФКЗ «О судах общей юрисдикции»), с другой - судья в соответствии с п. 48 ст. 5 УПК РФ является ее носителем, управомоченным на рассмотрение уголовного дела по существу и выносящим решения от имени Российской Федерации. Законодатель использует оба значения термина «суд» при конструировании норм УПК РФ. Если в одних случаях, например, при определении подсудности (ст. 30, 31 УПК РФ), суд - это орган, то в других должностное лицо, вступающее в правоотношения с иными участниками уголовного процесса. При этом в определенных случаях термин «суд» конкретизируется применительно к конкретным 
должностным лицам - мировому судье, председательствующему, председателю суда, его заместителям (например, ч. 5, 6 ст. 6.1, пп. 26 ст. 5, ст. 35 , ч. 3 ст. 401.8 , ч. 3 ст. 412.5 УПК РФ).

2. Самостоятельным признаком, характеризующим суд как участника уголовно-процессуальных отношений, можно назвать инстанционность. В этой связи необходимо отметить, что судебная инстанция детерминируется как «группа судебных органов и их структурных подразделений, наделенная равнозначными полномочиями по рассмотрению и разрешению уголовных дел в соответствующих стадиях уголовного судопроизводства». В настоящее время можно констатировать наличие четырех судебных инстанций: 1) суд первой инстанции, уполномоченный разрешать уголовное дело по существу с вынесением приговора, а также реализовывать контрольные полномочия в досудебных стадиях производства по уголовному делу и полномочия, связанные с исполнением судебного решения (п. 52 ст. 5, ст. 396-398 УПК РФ); 2) суд второй инстанции, т.е. апелляционный суд, рассматривающий жалобы и представления на судебные решения, не вступившие в законную силу; 3) суд кассационной инстанции, осуществляющий проверку вступивших в законную силу судебных решений по жалобам и представлениям заинтересованных лиц; 4) суд надзорной инстанции, контрольно-ревизионные полномочия которого имеют исключительный характер и реализуются Президиумом Верховного Суда РФ. Инстанционное построение судебной системы носит иерархический характер и позволяет осуществлять судебный контроль за деятельностью нижестоящих судов, а также служит правовым средством исправления возможных судебных ошибок, что имеет немаловажное значение с точки зрения механизма правозащитной деятельности в уголовном судопроизводстве. Кроме того, наличие судебных инстанций укладывается в систему уголовного судопроизводства, поскольку имеет определенную последовательность прохождения, соответствующую стадиям производства по уголовному делу.

3. Применительно к полномочиям судебной власти в уголовном процессе особое значение имеет состав суда, которым определяется «количественная совокупность и качественная характеристика лиц, уполномоченных осуществлять правосудие»². Анализ положений ст. 30 УПК РФ позволяет утверждать, что составы суда дифференцируются в зависимости

\footnotetext{
Бурмагин С.В. Статус и деятельность суда в уголовном процессе. М.: Проспект, 2016. С. 43.

Быков В.М. Проблемы суда первой инстанции // Российская юстиция. 2015. № 3. С. 25.
}

от категории уголовного дела, звена судебной системы и судебной инстанции: 1) судья единолично рассматривает по существу подавляющее большинство уголовных дел по первой инстанции, реализует контрольные полномочия в досудебном производстве, а также в стадии исполнения приговора. Кроме того, судья единолично рассматривает дела в апелляционном порядке в отношении судебных решений, выносимых мировыми судьями, а также в отношении решений по уголовным делам небольшой тяжести, рассмотренным районным судом и гарнизонным военным судом, и при пересмотре промежуточных решений указанных судов (ч. 3 и 4 ст. 30 УПК РФ); 2) коллегиальный состав суда включает в себя трех профессиональных судей либо одного профессионального судью и двенадцать присяжных заседателей, и допускается по незначительному перечню уголовных дел о тяжких и особо тяжких преступлениях (п. 2 и 3 ч. 2 ст. 30 УПК РФ)3. Коллегиальный состав суда предусмотрен для вышестоящих судебных инстанций, реализующих контрольно-ревизионные полномочия.

4. Полномочия суда имеют исключительный характер, поскольку не могут быть делегированы иным участникам уголовного судопроизводства. Их содержание характеризуется отсутствием личного либо публичного интереса в исходе уголовного дела, что является гарантией независимости и самостоятельности судебной власти. Кроме того, при регламентации полномочий суда законодатель использует исчерпывающий перечень, что не допускает диспозитивности при толковании соответствующих норм, поскольку суд является органом, ответственным за ход и результат судебного процесса, гарантом защиты прав и интересов сторон. С точки зрения форм реализации права судебная деятельность имеет правоприменительный характер, так как заключается в разрешении конкретного правового спора, вытекающего из фактических обстоятельств уголовного дела на основе норм материального и процессуального права. Это предполагает наличие у суда ответственности за законность, обоснованность, мотивированность принимаемых решений. Как справедливо отмечается в специальной литературе, такая ответственность не может быть персонифицирована, поскольку проявляется

\footnotetext{
Названный состав суда подвергся значительным изменениям. В соответствии с Федеральным законом от 23.06.2016 № 190-Ф3 «О внесении изменений в Уголовно-процессуальный кодекс Российской Федерации в связи с расширением применения института присяжных заседателей» число присяжных заседателей в областных, окружных и верховных судах с 01.06.2017 уменьшено до восьми человек, а в районных и городских судах коллегия присяжных будет состоять из шести человек.
} 
в виде негативных процессуальных последствий - отмены или изменения судебного решения вышестоящей инстанцией, увеличения сроков производства по уголовному делу и т.д. ${ }^{4}$

С учетом названной специфики правовой статус суда сформулирован законодателем путем закрепления его полномочий в ст. 29 УПК РФ. Переходя к вопросу о формах реализации судебной власти в уголовном судопроизводстве, позволим себе охарактеризовать данные полномочия, применив именно функциональный критерий, позволяющий разделить их на несколько групп: 1) полномочия по разрешению уголовного дела по существу; 2) полномочия по контролю за деятельностью органов предварительного расследования; 3) полномочия суда по рассмотрению жалоб на действия (бездействие) и решения должностных лиц, ведущих производство по уголовному делу (ч. 3 ст. 29 и ст. 125 УПК РФ); 4) полномочия по реагированию на допущенные в ходе производства по уголовному делу нарушения прав и свобод граждан, принципа законности, установленные обстоятельства, способствовавшие совершению преступления путем вынесения частного определения или постановления.

Разрешение уголовного дела по существу предполагает реализацию судом полномочий, закрепленных в ч. 1 ст. 29 УПК РФ, а именно: признание лица виновным в совершении преступления и назначение ему наказания; применение к лицу принудительных мер медицинского характера; применение к лицу принудительных мер воспитательного воздействия; прекращение уголовного дела в соответствии со ст. 25.1 УПК РФ с назначением судебного штрафа5; отмена или изменение решения, принятого нижестоящим судом.

Следует отметить, что совокупность названных выше полномочий, по мнению определенной части ученых-процессуалистов, формирует содержание понятия «правосудие». В качестве аргументов традиционно приводятся следующие доводы. Во-первых, разрешение уголовного дела по существу является основной судебной функцией, которая корреспондирует назначению судебной власти, в то время как иные полномочия суда можно отнести к числу субсидиарных,

\footnotetext{
4 См.: Качалова О.В. Функции суда в современном российском уголовном судопроизводстве // Российский судья. 2014 . № 1. С. 8.

Указанное полномочие было введено Федеральным законом от 03.07.2016 № 323-Ф3 «О внесении изменений в Уголовный кодекс Российской Федерации и Уголовно-процессуальный кодекс Российской Федерации по вопросам совершенствования оснований и порядка освобождения от уголовной ответственности» в качестве альтернативы уголовному наказанию по делам небольшой и средней тяжести.
}

не охватываемых понятием «правосудие» ${ }^{6}$. Вовторых, акты, выносимые судом в ходе реализации субсидиарных полномочий, не обладают свойствами приговора как основного акта правосудия 7 . Думается, что приведенная точка зрения, унифицирующая подход к понятию «правосудие», в современных правовых реалиях является достаточно спорной. Так, мы солидарны с позицией Л.А. Воскобитовой о том, что правосудие по содержанию - это правоприменительная деятельность суда, реализуемая в различных формах, в числе которых и судебный контроль, и судебное санкционирование, и контрольно-ревизионная деятельность вышестоящих судебных инстанций ${ }^{8}$ В данном контексте к правосудию может быть отнесена любая судебная деятельность, осуществляемая в предусмотренной законом форме, основы которой определены на конституционном уровне (непосредственность, непрерывность, гласность, устность, неизменность состава суда и т.д.). Дополнительным аргументом может, на наш взгляд, являться и позиция законодателя, который толкует форму реализации судебной власти именно как правосудие, осуществляемое в ходе судебного заседания в досудебных и судебных стадиях производства по уголовному делу (п. 50 ст. 5 УПК РФ).

Контроль за деятельностью органов предварительного расследования является самостоятельным направлением судебной деятельности, которое осуществляется в нескольких формах.

1. Применение мер принуждения, существенным образом ограничивающих конституционные права и свободы участников уголовного судопроизводства. В соответствии с ч. 2 ст. 29 УПК РФ к числу таких мер относятся заключение под стражу, домашний арест, залог, а также продление срока содержания под стражей или срока домашнего ареста, применение иных мер принуждения (временное отстранение подозреваемого или обвиняемого от должности, денежное взыскание). Заметим, что, несмотря на исключительный характер названных полномочий суда, их реализация судебной властью является пассивной, поскольку соответствующее ходатайство

6 См., например: Банников И.А. Принцип осуществления правосудия только судом: историко-правовой аспект // Арбитражный и гражданский процесс. 2017. № 2. С. 53.

См.: Зинатуллин 3.3. Проблемы уголовного процесса России. Ижевск: Детектив-информ, 2008. С. 70; Азарова В.А., Таричко И.Ю. Функция судебного контроля в истории, теории и практике уголовного процесса России. Омск: Омск. гос. университет, 2004. С. 133.

8 С.: Воскобитова Л.А. Существенные нарушения уголовно-процессуального закона как основание к отмене приговора: дисс. ... канд. юрид. наук. М., 1979. С. 181. 
вносится должностным лицом, ведущим производство по уголовному делу (ст. 107-109 УПК РФ). В соответствии с ч. 3 ст. 389.2 УПК РФ ограничение конституционных прав на свободу и личную неприкосновенность, права частной собственности, составляющих предмет судебной деятельности, может быть обжаловано заинтересованными лицами еще до вынесения итогового решения по уголовному делу.

С учетом приведенного выше тезиса о том, что рассматриваемый вид деятельности является элементом понятия «правосудие», его форма носит состязательный характер, поскольку судебное заседание по решению вопросов о применении мер принуждения проводится с участием сторон, которые отстаивают свою процессуальную позицию путем представления доказательств, подлежащих непосредственному исследованию судом ${ }^{9}$. В этой связи позиция законодателя относительно ряда организационных вопросов, касающихся порядка уведомления сторон, рассмотрения ходатайств участников судебного заседания, остается неясной. В связи с отсутствием законодательной регламентации в специальной литературе высказывается точка зрения о том, что коль скоро инициатива применения меры принуждения принадлежит дознавателю (следователю), именно он должен нести обязанность уведомления заинтересованных лиц о дате, месте и времени судебного заседания ${ }^{10}$. Мы категорически не согласны с таким подходом, поскольку он не соответствует сущности состязательного судебного процесса, а также порядку его организации, предусмотренному, например, для рассмотрения уголовного дела по существу, когда суд, используя весь арсенал имеющихся у него процессуальных средств, извещает стороны о судебном заседании (ст. 232, 389.12, 401.12 УПК РФ). Традиционно в подготовительной части судебного заседания рассматривается вопрос о возможности слушания дела в отсутствие кого-либо из вызванных участников судопроизводства. Как следует из смысла ч. 4 ст. 108 УПК РФ в судебном заседании при решении вопроса о применении меры пресечения обязательно участие обвиняемого (подозреваемого), прокурора, защитника. Кроме того, соответствующим правом обладают законный представитель несовершеннолетнего обвиняемого (подозреваемого), руководитель следственного органа, следователь, дознаватель. Принципиальное значение имеет

\footnotetext{
См.: Печегин Д.А. Состязательное начало уголовного судопроизводства // РЖПИ. 2017. № 1. С. 171-176.

См.: Конярова Ж.К. Реализация дискреционных полномочий прокурора при избрании меры пресечения в виде заключения под стражу по ходатайству следователя // Вестник Оренб. ун-та. 2008. № 83. С. 42.
}

явка обвиняемого (подозреваемого), к которому мера пресечения избирается только в его присутствии, за исключением случая объявления его в международный розыск (ч. 5 ст. 108 УПК РФ). Такой подход в специальной литературе неоднократно подвергался критике на том основании, что практическая реализация положений ч. 5 ст. 108 УПК РФ затруднена в случаях, когда обвиняемый скрылся и объявлен в местный либо федеральный розыск" ${ }^{11}$ Верховный Суд РФ, учитывая позицию правоприменителя, допускает расширительное толкование ч. 5 ст. 108 УПК РФ при условии достоверного установления того факта, что обвиняемый (подозреваемый) скрылся от органов предварительного расследования и суда ${ }^{12}$ и признает соответствующую практику судов законной ${ }^{13}$.

2. Санкционирование производства следственных действий ${ }^{14}$, сопряженных с ограничением конституционных прав и свобод граждан: осмотр жилища при отсутствии согласия проживающих в нем лиц; обыск и выемка в жилище; выемка заложенной или сданной на хранение в ломбард вещи; обыск, осмотр и выемка в отношении адвоката ${ }^{15}$; личный обыск, за исключением случаев, предусмотренных ст. 93 УПК РФ; выемка предметов и документов, содержащих государственную или иную охраняемую федеральным законом тайну, а также предметов и документов, содержащих информацию о вкладах и счетах граждан в банках и иных кредитных организациях; наложение ареста на корреспонденцию, разрешение на ее осмотр

\footnotetext{
11 См., например: Барабаш А.С. Основания для избрания заключения под стражу, домашнего ареста, залога и их доказывание // Российский юридический журнал. 2016. № 5. С. 143; Щерба С.П., Попова А. В. Дискреционные полномочия прокурора при применении меры пресечения в виде заключения под стражу // Законность. 2016. № 1. С. $22-26$.
}

12 См.: п. 14 постановления Пленума ВС РФ от 19.12.2013 № 41 «О практике применения судами законодательства о мерах пресечения в виде заключения под стражу, домашнего ареста и залога».

13 См.: Обзор практики рассмотрения судами ходатайств об избрании меры пресечения в виде заключения под стражу и о продлении срока содержания под стражей, утв. Президиумом ВС РФ 18.01.2017.

14 Решение о производстве следственного действия имеет все признаки, детерминирующие понятие «санкция», т.е. одобрение какого-либо действия или решения, поскольку носит разрешительный характер, являясь процессуальным условием начала производства соответствующего следственного действия, а также является окончательным, так как не требует согласования с каким-либо иным органом или должностным лицом.

5 Пункт 5.2 ч. 2 ст. 29 УПК РФ введен в действие Федеральным законом от 17.04.2017 № 73-Ф3 «О внесении изменений в Уголовно-процессуальный кодекс Российской Федерации». 
и выемку в учреждениях связи; наложение ареста на имущество; контроль и запись телефонных и иных переговоров; получение информации о соединениях между абонентами и (или) абонентскими устройствами.

Названная группа полномочий суда имеет исключительный характер, что следует из формулировки законодателя, предваряющей перечень следственных действий, составляющих предмет судебной деятельности, - «только суд, в том числе в ходе досудебного производства, правомочен принимать решения...». Вместе с тем исключительность полномочий суда в данном случае имеет бинарную природу, поскольку в соответствии с ч. 5 ст. 165 УПК РФ в случаях, не терпящих отлагательства, последовательность действий может быть обратной - производство следственного действия предшествует судебному решению о его законности и обоснованности, которое с точки зрения получения доказательств все равно имеет определяющее значение.

Форма судебной деятельности по санкционированию производства следственных действий совпадает с процессуальным порядком применения мер принуждения, рассмотренным выше, что позволяет говорить об унификации соответствующей процедуры, формирующей, как уже было отмечено, единое направление деятельности суда в уголовном процессе. Вместе с тем данные виды деятельности не являются тождественными, поскольку имеют определенные отличия, которые, на наш взгляд, заключаются в следующем. Так, суд не несет ответственности за законность и обоснованность производства следственного действия, ограничивающего конституционные права и свободы граждан, поскольку решение о его производстве, хоть и санкционируется судом, но принимается должностным лицом, ведущим предварительное расследование (ч. 2 ст. 38, ч. 3 ст. 41 УПК РФ), поскольку является частью его тактики. Соответственно, судебное решение о производстве следственного действия можно детерминировать как необходимое условие законности такового. Мы позволим себе солидаризироваться с позицией, высказанной В.Ф. Васюковым, о том, что непосредственное ограничение прав участников судопроизводства осуществляется дознавателем, следователем в процессе совершения действий, обозначенных в ч. 2 ст. 29 УПК РФ'. Кроме того, судебное санкционирование в отличие от применения мер принуждения имеет

\footnotetext{
16 См.: Васюков В.Ф. Некоторые вопросы проведения следственных действий, направленных на обнаружение, фиксацию и изъятие электронных сообщений, переданных посредством мобильных абонентских устройств сотовой связи // Российский следователь. 2016. № 23. С. 16.
}

проверочный характер, поскольку его процедура предполагает проверку судом наличия или отсутствия оснований для производства запрашиваемого органами расследования следственного действия. И, наконец, в самой процедуре санкционирования, предусмотренной ст. 165 УПК РФ, отсутствуют элементы состязательности, так как законодатель не предполагает участия сторон в судебном заседании, ограничиваясь лишь предоставлением соответствующего права должностному лицу, заявившему соответствующее ходатайство. В специальной литературе высказываются предложения о предоставлении права на участие в судебном заседании заинтересованным лицам, например, защитнику, подозреваемому, обвиняемому, потерпевшему굴. Полагаем, что такая позиция не свободна от критики, поскольку позитивный результат следственного действия в подавляющем большинстве случаев обусловлен внезапностью и конфиденциальностью его производства, что невозможно при привлечении к участию в судебном заседании указанных лиц. Кроме того, при не достижении искомого результата следственного действия нивелируется значение его исключительного характера, сопряженного с ограничением конституционных прав граждан, делая его бессмысленным с доказательственной точки зрения. Гарантией прав и законных интересов лиц, в отношении которых проводятся следственные действия, может служить возможность обжалования соответствующего постановления судьи в вышестоящую судебную инстанцию, а также инициирование процедуры судебного контроля, предусмотренной ст. 125 УПК РФ.

В связи с процедурой судебного санкционирования наиболее острые дискуссии в специальной литературе вызывает его предмет, недостаточно детализированный законодателем, который ограничился лишь установлением требований процессуальной формы, а именно:

1) согласование ходатайства о производстве следственного действия с руководителем следственного органа либо с прокурором;

2) срок рассмотрения ходатайства составляет 24 часа с момента поступления материалов в суд по месту производства предварительного расследования (следственного действия);

3) участие в судебном заседании представителя стороны обвинения (прокурора, следователя и дознавателя);

4) перечень решений, принимаемых судом по результатам рассмотрения ходатайства.

\footnotetext{
См., например: Вилкова Т.Ю. Принцип неприкосновенности жилища в уголовном судопроизводстве: правовые основы, содержание, гарантии // Актуальные проблемы российского права. 2015. № 2. С. 103-107.
} 
Сама процедура познавательной деятельности суда остается за пределами правового регулирования, что объясняется «наличием специфики каждого конкретного случая, обусловленного совокупностью обстоятельств уголовного дела» ${ }^{18}$. Позволим себе усомниться в справедливости данного тезиса, поскольку анализ положений ст. 182-186 УПК РФ позволяет сформулировать ряд вопросов, подлежащих исследованию в судебном заседании:

1) наличие постановления о возбуждении уголовного дела, которое является процессуальным условием производства следственных действий, предусмотренных ч. 2 ст. 29 УПК РФ, за исключением тех, которые в соответствии с ч. 1 ст. 144 УПК РФ могут проводиться в рамках проверки сообщения о преступлении (например, осмотр места происшествия без согласия проживающих в нем лиц);

2) наличие фактического основания производства следственного действия, которое легально установлено для каждого из них. Например, при производстве выемки должностное лицо, ведущее производство по уголовному делу, должно точно знать, где и у кого находятся искомые предметы и документы (ч. 1 ст. 183 УПК РФ);

3) исключительный характер ограничения конституционных прав участников уголовного судопроизводства, возможных при производстве запрашиваемого следственного действия. В специальной литературе называются различные способы удостоверительной деятельности суда в рассматриваемом случае. Например, С.И. Ковалева полагает, что следователь (дознаватель) должен предоставить суду информацию о средствах доказывания, использовавшихся ранее, но оказавшихся безрезультатными ${ }^{19}$. C.А. Шейфер указывает, что положительное решение суда по ходатайству, поданному в порядке ст. 165 УПК РФ, может быть получено при отсутствии иных легитимных путей получения искомой информации ${ }^{20}$.

Что касается рассмотрения жалоб на действия (бездействие) и решения должностных лиц, ведущих производство по уголовному делу, то в отличие от иных полномочий суда данное полномочие не обладает свойством исключительности, поскольку аналогичные полномочия в соответствии со ст. 124 УПК РФ

\footnotetext{
18 См.: Стельмах В.Ю. Несоблюдение процессуальной формы следственных действий: виды и последствия // Уголовное право. 2015. № 6. С. 108.

19 См.: Ковалева С.И. К вопросу об участии судьи в доказывании при осуществлении судебного контроля на предварительном расследовании // Российская юстиция. 2014. № 4. С. 23-26.

См.: Шейфер С.А. Доказательства и доказывание по уголовным делам. М.: Норма, 2008. С. 71.
}

предоставлены прокурору и руководителю следственного органа. По своему характеру полномочия по рассмотрению жалоб заинтересованных лиц имеют правовосстановительную природу, так как их реализация судом устраняет допущенные органами расследования нарушения конституционных прав граждан.

В специальной литературе полномочия суда, предусмотренные ч. 3 ст. 29 УПК РФ, детерминируются как судебный контроль ${ }^{21}$. Анализ обширной библиографии вопроса позволяет выделить несколько специфических признаков контрольной деятельности судебных органов. Вопервых, отсутствие иерархической подчиненности, характерной для ведомственного контроля, что обусловлено тем фактом, что суд не относится к числу правоохранительных органов, имеющих соответствующую структуру. Кроме того, рассмотрение жалоб на действия (бездействие) и решения должностных лиц органов предварительного расследования не связано с инстанционностью судебной системы и осуществляется судом по месту совершения деяния, содержащего признаки преступления либо по месту производства предварительного расследования. Во-вторых, суд не является инициатором контрольной деятельности, поскольку реализует полномочия, предусмотренные ст. 125 УПК РФ лишь при наличии жалобы заинтересованного лица, которое может выбрать и иной порядок защиты своих нарушенных прав, предусмотренный гл. 16 УПК РФ. В-третьих, реализуя полномочия в рамках судебного контроля, суд принимает промежуточные решения, в которых констатируется наличие (отсутствие) нарушения, подлежащего устранению органом, его допустившим. В-четвертых, с содержательной точки зрения судебный контроль представляет собой совокупность трех действий: выявление нарушения, обеспечение его устранения и анализ факторов его возникновения ${ }^{22}$.

Процедура рассмотрения жалобы имеет состязательный характер. Так, инициатором судебного контроля, как уже было отмечено, является лицо, подавшее жалобу. При этом диспозитивная природа названного права характеризуется отсутствием легальных требований к форме и содержанию обращения в суд, что в специальной литературе оценивается

\footnotetext{
21 См., например: Лопаткина Н.А. Институт судебного контроля на досудебных стадиях уголовного процесса России: Дисс. ... канд. юрид. наук. Краснодар, 2002. C. 49; Рябцева Е.В. Правосудие в уголовном процессе России: Монография. 2-е изд., доп. М.: Юрлитинформ, 2010. С. $12-13$.

22 См.: Горшенев В.М., Шахов И.Б. Контроль как правовая форма деятельности. М.: Юридическая литература, 1987. C. 23.
} 
позитивно с точки зрения реализации принципа свободы обжалования и механизма защиты прав и законных интересов лиц, вовлеченных в орбиту уголовного судопроизводства ${ }^{23}$. Мы позволим себе солидаризироваться с иной позицией. Несомненной поддержки законодателя, на наш взгляд, заслуживает предложение о введении правила «необходимого минимума реквизитов» ${ }^{24}$, которое предусматривает перечень сведений, составляющих содержание любого официального документа, а именно, данные о: заявителе, его месте жительства, процессуальном статусе; органе, действия и решения которого обжалуются и которому адресуется жалоба. Указание в тексте документа названных сведений не составляет труда для заинтересованного лица, однако существенно упростит прием и рассмотрение жалобы, а, следовательно, послужит дополнительной гарантией доступа граждан к правосудию. На необходимость уточнения содержания жалобы с точки зрения формальных реквизитов неоднократно указывалось в обобщениях судебной практики применения ст. 125 УПК РФ, сделанных судами различного уровня ${ }^{25}$. Кроме того, соответствующее дополнение текста рассматриваемой нормы уголовно-процессуального закона позволило бы, на наш взгляд, унифицировать общие требования к жалобам, подаваемым в различные судебные инстанции в процессе производства по уголовному делу, поскольку ст. 389.6, 401.4 УПК РФ уже содержат критерии содержательной допустимости апелляционной и кассационной жалоб. Аналогичным образом должен решаться вопрос о форме подачи жалобы, поскольку отсутствие критериев таковой, прямо закрепленных в ст. 125 УПК РФ, позволяет делать утверждение о допустимости устного обращения за судебной защитой, что влечет за собой процедуру личного приема заявителя в суде, что не вполне приемлемо в состязательной процедуре.

Группа полномочий суда по реагированию на допущенные в ходе производства по уголовному делу нарушения прав и свобод граждан, принципа законности, установленные

\footnotetext{
23 См., например: См.: Амельков Н.С. Заявитель в уголовном судопроизводстве России // Актуальные проблемы российского права. 2013. № 5. С. 590-594.

24 Махоркин И.Л. Полномочия суда и их реализация на стадии предварительного расследования: Дисс. ... канд. юрид. наук. М., 2009. С. 34.

25 См.: Практика применения Уголовно-процессуального кодекса Российской Федерации. Актуальные вопросы судебной практики, рекомендации судей ВС РФ по применению уголовно-процессуального законодательства на основе новейшей судебной практики. 7-е изд., перераб. и доп. / Под ред. В.М. Лебедева. М.: Юрайт, 2016. С. 89.
}

обстоятельства, способствовавшие совершению преступления, носит профилактический характер, так как основной целью их реализации является предотвращение «возникновения угрозы субъективному праву или государственным интересам в дальнейшей деятельности должностных лиц и организаций» ${ }^{26}$. Актом реагирования в данном случае выступает частное определение (постановление) суда об устранении допущенных нарушений, подлежащее немедленному исполнению.

Практически все указанные выше функции включают в себя правозащитные элементы, что позволяет говорить об их направленности на решение совокупности задач уголовного судопроизводства, закрепленных в ст. 6 УПК РФ.

\section{Список литературы}

1. Азарова В.А., Таричко И.Ю. Функция судебного контроля в истории, теории и практике уголовного процесса России. Омск: Омск. гос. университет, 2004. 379 с.

2. Амельков Н.С. Заявитель в уголовном судопроизводстве России // Актуальные проблемы российского права. 2013. № 5. С. 590-594.

3. Банников И.А. Принцип осуществления правосудия только судом: историко-правовой аспект // Арбитражный и гражданский процесс. 2017. № 2. С. 52-57.

4. Барабаш А.С. Основания для избрания заключения под стражу, домашнего ареста, залога и их доказывание // Российский юридический журнал. 2016. № 5. С. 143-149.

5. Бурмагин С. В. Статус и деятельность суда в уголовном процессе. М.: Проспект, 2016. 304 с.

6. Быков В.М. Проблемы суда первой инстанции // Российская юстиция. 2015. № 3. С. 25-27.

7. Васюков В.Ф. Некоторые вопросы проведения следственных действий, направленных на обнаружение, фиксацию и изъятие электронных сообщений, переданных посредством мобильных абонентских устройств сотовой связи // Российский следователь. 2016. № 23. С. 15-18.

8. Вилкова Т.Ю. Принцип неприкосновенности жилища в уголовном судопроизводстве: правовые основы, содержание, гарантии // Актуальные проблемы российского права. 2015. № 2. С. 103-107.

9. Воскобитова Л.А. Существенные нарушения уголовно-процессуального закона как основание к отмене приговора: Дисс. ... канд. юрид. наук. М., 1979. 186 с.

10. Горшенев В.М., Шахов И.Б. Контроль как правовая форма деятельности. М.: Юридическая литература, 1987. 176 с.

11. Зинатуллин 3.3. Проблемы уголовного процесса России. Ижевск: Детектив-информ, 2008. 284 с.

26 Рыжих А.Н. Полномочия суда на досудебных стадиях уголовного процесса: Дисс. ... канд. юрид. наук. Екатеринбург, 2008. С. 29. 
12. Качалова О.В. Функции суда в современном российском уголовном судопроизводстве // Российский судья. 2014 . № 1. С. 8-10.

13. Ковалева С.И. К вопросу об участии судьи в доказывании при осуществлении судебного контроля на предварительном расследовании // Российская юстиция. 2014. № 4. С. 23-26.

14. Конярова Ж.К. Реализация дискреционных полномочий прокурора при избрании меры пресечения в виде заключения под стражу по ходатайству следователя // Вестник Оренб. ун-та. 2008. № 83. С. 41-43.

15. Лопаткина Н.А. Институт судебного контроля на досудебных стадиях уголовного процесса России: Дисс. ... канд. юрид. наук. Краснодар, 2002. 187 с.

16. Махоркин И.Л. Полномочия суда и их реализация на стадии предварительного расследования: Дисс. ... канд. юрид. наук. М., 2009. 174 с.

17. Печегин Д.А. Состязательное начало уголовного судопроизводства // РЖПИ. 2017. № 1. С. 171-176.

18. Практика применения Уголовно-процессуального кодекса Российской Федерации. Актуальные вопросы судебной практики, рекомендации судей ВС РФ по применению уголовно-процессуального законодательства на основе новейшей судебной практики. 7-е изд., перераб. и доп. / Под ред. В.М. Лебедева. М.: Юрайт, 2016. 231 с.

19. Рыжих А.Н. Полномочия суда на досудебных стадиях уголовного процесса: Дисс. ... канд. юрид. наук. Екатеринбург, 2008.187 с.

20. Рябцева Е.В. Правосудие в уголовном процессе России. 2-е изд., доп. М.: Юрлитинформ, 2010. 400 с.

21. Стельмах В.Ю. Несоблюдение процессуальной формы следственных действий: виды и последствия // Уголовное право. 2015. № 6. С. 108-117.

22. Шейфер С.А. Доказательства и доказывание по уголовным делам. М.: Норма, 2008. 125 с.

23. Щерба С.П., Попова А.В. Дискреционные полномочия прокурора при применении меры пресечения в виде заключения под стражу // Законность. 2016. № 1. С. 22-26.

\title{
Forms of Implementation of the Judiciary in Criminal Proceeding in the Context of the Procedural Status of the Court as a Participant in Criminal Proceeding
}

Lutsenko P.A., $\mathrm{PhD}$ in Law, Associate Professor of the Department of Criminal Law and Criminal Procedure, Voronezh GAU named after Emperor Peter I

\begin{abstract}
The article examines the procedural status of the court as a participant of criminal proceedings taking into account the specifics of its legal position and the functions to be implemented. The legal status of the court in criminal proceedings by the absence of public or personal interest in the outcome of the criminal case, which not only predetermines the adversarial form of the proceedings, but also guarantees the independence of the judicial authorities in the exercise of justice. The author concludes that the concept of «court» is collective, since on the one hand it is a state institution entering the judicial system, on the other hand - the judge is the bearer of power, considering the criminal case on the merits and decisions provided by law.

The judicial system has a sign of instancionnosti, due to its internal hierarchical structure. The existence of judicial bodies predetermines the movement of criminal proceedings, is a structural mechanism for the implementation of the function of internal judicial control and supervision, and also protects the rights and legitimate interests of participants in the criminal Legal proceedings and other interested persons. The powers of the court are considered from the standpoint of the functional criterion, namely: the resolution of the criminal case on the merits; monitoring of the activities of the preliminary investigation bodies; consideration of complaints on actions (inaction) and decisions of officials, conducting proceedings in a criminal case; response to violations of the rights and freedoms of citizens, the principle of legality, established circumstances, which contributed to the commission of a crime by making a private determination or decision, in the course of criminal proceedings.

Keywords: court, resolution of the criminal case on the merits, the judicial control, approval, complaint, coercive measures, investigations.
\end{abstract}

\section{References}

1. Azarova V.A., Tarichko I.Yu. Funktsiya sudebnogo kontrolya v istorii, teorii i praktike ugolovnogo protsessa Rossii. Omsk: Omsk. gos. universitet, 2004. 379 s. 
2. Amelkov N.S. Zayavitel v ugolovnom sudoproizvodstve Rossii // Aktualnye problemy rossijskogo prava. 2013. № 5. S. 590-594.

3. Bannikov I. A. Printsip osuschestvleniya pravosudiya tolko sudom: istoriko-pravovoj aspekt // Arbitrazhnyj i grazhdanskij protsess. 2017. № 2. S. 52-57.

4. Barabash A.S. Osnovaniya dlya izbraniya zaklyucheniya pod strazhu, domashnego aresta, zaloga i ikh dokazyvanie // Rossijskij yuridicheskij zhurnal. 2016. № 5. S. 143-149.

5. Burmagin S.V. Status i deyatelnost suda v ugolovnom protsesse. M.: Prospekt, 2016. 304 s.

6. Bykov V.M. Problemy suda pervoj instantsii // Rossijskaya yustitsiya. 2015. № 3. S. 25-27.

7. Vasyukov V.F. Nekotorye voprosy provedeniya sledstvennykh dejstvij, napravlennykh na obnaruzhenie, fiksatsiyu i izyatie elektronnykh soobschenij, peredannykh posredstvom mobilnykh abonentskikh ustrojstv sotovoj svyazi // Rossijskij sledovatel. 2016. № 23. S. 15-18.

8. Vilkova T.Yu. Printsip neprikosnovennosti zhilischa v ugolovnom sudoproizvodstve: pravovye osnovy, soderzhanie, garantii // Aktualnye problemy rossijskogo prava. 2015. № 2. S. 103-107.

9. Voskobitova L.A. Suschestvennye narusheniya ugolovno-protsessualnogo zakona kak osnovanie k otmene prigovora: Diss. ... kand. yurid. nauk. M., 1979. 186 s.

10. Gorshenev V.M., Shakhov I. B. Kontrol kak pravovaya forma deyatelnosti. M.: Yuridicheskaya literatura, $1987.176 \mathrm{s.}$

11. Zinatullin Z.Z. Problemy ugolovnogo protsessa Rossii. Izhevsk: Detektiv-inform, 2008. 284 s.

12. Kachalova O.V. Funktsii suda v sovremennom rossijskom ugolovnom sudoproizvodstve // Rossijskij sudya. 2014. № 1. S. 8-10.

13. Kovaleva S.I. K voprosu ob uchastii sudi v dokazyvanii pri osuschestvlenii sudebnogo kontrolya na predvaritelnom rassledovanii // Rossijskaya yustitsiya. 2014. № 4. S. 23-26.

14. Konyarova Zh.K. Realizatsiya diskretsionnykh polnomochij prokurora pri izbranii mery presecheniya $\mathrm{v}$ vide zaklyucheniya pod strazhu po khodatajstvu sledovatelya // Vestnik Orenb. un-ta. 2008. № 83. S. 41-43.

15. Lopatkina N.A. Institut sudebnogo kontrolya na dosudebnykh stadiyakh ugolovnogo protsessa Rossii: Diss. ... kand. yurid. nauk. Krasnodar, 2002. 187 s.

16. Makhorkin I. L. Polnomochiya suda i ikh realizatsiya na stadii predvaritelnogo rassledovaniya: Diss. ... kand. yurid. nauk. M., 2009. 174 s.

17. Pechegin D.A. Sostyazatelnoe nachalo ugolovnogo sudoproizvodstva // RZHPI. 2017. № 1. S. 171-176.

18. Praktika primeneniya Ugolovno-protsessualnogo kodeksa Rossijskoj Federatsii. Aktualnye voprosy sudebnoj praktiki, rekomendatsii sudej VS RF po primeneniyu ugolovno-protsessualnogo zakonodatelstva na osnove novejshej sudebnoj praktiki. 7-e izd., pererab. i dop. / Pod red. V.M. Lebedeva. M.: Yurajt, 2016. $231 \mathrm{~s}$.

19. Ryzhikh A.N. Polnomochiya suda na dosudebnykh stadiyakh ugolovnogo protsessa: Diss. ... kand. yurid. nauk. Ekaterinburg, $2008.187 \mathrm{~s}$.

20. Ryabtseva E.V. Pravosudie v ugolovnom protsesse Rossii. 2-e izd., dop. M.: Yurlitinform, 2010. 400 s.

21. Stelmakh V.Yu. Nesoblyudenie protsessualnoj formy sledstvennykh dejstvij: vidy i posledstviya // Ugolovnoe pravo. 2015. № 6. S. 108-117.

22. Shejfer S.A. Dokazatelstva i dokazyvanie po ugolovnym delam. M.: Norma, 2008. $125 \mathrm{~s}$.

23. Scherba S.P., Popova A.V. Diskretsionnye polnomochiya prokurora pri primenenii mery presecheniya v vide zaklyucheniya pod strazhu // Zakonnost. 2016. № 1. S. 22-26. 